the I 8-pounder, the howitzer, and the mortar, resembled noiseless jets of steam, projected, "so to speak, at our elbows."

Royal Institution, Nov. 17 JOHN TYNDALL

CHARLES BLACKER VIGNOLES, F.R.S.

T

HIS celebrated engineer died on the $r 7$ th instant at Hythe, at the age of eighty-three years. Although he won his fame mainly as an engineer, yet his services to science were of considerable importance. Mr. Vignoles was descended from an ancient French family which had taken refuge in England after the repeal of the Edict of Nantes. His father, Capt. Vignoles, was an officer in the 43rd Regiment of the Line, and his mother was a daughter of Dr. Charles Hutton, the celebrated mathematician and professor at the Royal Military Academy, Woolwich. When young Vignoles was only twelve months old, his father lost his life at the storming of Pointe-à-Pierre, Guadaloupe, when Sir Charles Grey, the commander of the British forces, gave the former a commission in the army. Thus his career has been an unprecedentedly long one. His grandfather, Dr. Hutton, undertook his education, and the pupil certainly turned out a credit to his teacher. For a short time before the conclusion of the great war which ended in 1815 , Vignoles served under the Duke of Wellington on the Continent, and after visiting America about I822, he returned to England and threw himself enthusiastically into the engineering profession. The railway movement was just then gathering strength, and Vignoles was associated with some of the earliest efforts to establish lines in this country. After the Liverpool and Manchester Railway Bill was thrown out of Parliament in 1824 , he was, in I 825 , selected by Messrs. Rennie to take charge of the new surveys which the Liverpool Committee ordered. From this time forward Vignoles was ever in the van of the railway movement, and had the foresight to predict, amid some incredulity and ridicule, to what gigantic results it would lead. In. 1826 he was employed by Messrs. Rennie to make surveys for a line from Nine EIms, Vauxhall, Dorking and Shoreham, to Brighton; and in 1834 he escorted $M$. Thiers over the railways which had been built under his superintendence. The great French Minister's dictum was, "I do not think railways are suited for France." In England, in Ireland, on the Continent, and in America, Mr. Vignoles took a prominent part in the carrying out of great railway and other engineering works. Probably one of his greatest works was the magnificent suspension bridge over the Dnieper at Kieff, commenced in 1848 and finished in 1853 , at a cost of 432,000 . A fine model of this is now in the Crystal Palace.

Mr. Vignoles became a member of the Institution of Civil Engineers in 1827 , and was elected President in 1870 , when he gave a very able address on the progress of en yineering. In 1842 he gave a series of remarkable lectures as Professor of Civil Engineering at London University College. In I 855 he was elected a Fellow of the Royal Society; he was also a Fellow of the Royal Astronomical Society, and was for long a regular attendant at its meetings. The Eclipse party of 1860 was to a great extent indebted to him for all the local arrangements, and its success was mainly due to his exertions. $\mathrm{He}_{\mathrm{\alpha}}$ was also Honorary Treasurer of the Expedition of I870, was on board the Psyche when she struck, and was afterwards indefatigable in aiding the necessary arrangements. In the early part of its career he took an active part in the meetings of the British Association, contributing several papers to the Mechanical Section.

As might be expected, Mr. Vignoles was a man of great energy and strong physical constitution. On the Thursday before his death he attended the annual inspection, in his capacity of Lieutenant-Colonel, of the Engineers and Railway Volunteer Staff Corps, On the Saturday following he was struck with paralysis, and remained unconscious till his death on the following Wednesday. He was buried yesterday at the Brompton Cemetery.

\section{THE GERMAN COMMISSION ON ARCTIC EXPLORATION}

FURTHER details concerning the work of this Commission appear in a recent number of the Karlsruher Zeitung.

The Commission cannot recommend another Arctic expedition. The task of special geographical discovery, to whose solution previous expeditions have contributed, must, since the polar regions have been opened up at many points, give place to the task of exploring in detail the region of which we now have a general knowledge, and on the results thus attained to construct a sure basis for wider researches. "Without such an established basis, every new Arctic expedition might, according to the circumstances, accomplish more or less good results, but for this a considerable expenditure of public means would be the less advisable, that we may have a sure expectation, by following a different course from that hitherto pursued, of accomplishing, more slowly perhaps, but all the more surely, the exploration of the Arctic zone, and at the same time solve very important problems in science."

The Commission unanimously agree that the exploration of the Arctic region should be undertaken. The last part of the Report, without pretending to be complete, discusses very important questions in all departments of science, the solution of which is to be obtained by Arctic exploration. The majority of meteorological and hydrographic problems, many questions in the regions of terrestrial magnetism and physical astronomy, a number of questions in the department of natural science, in other words, the discovery of the laws of periodical phenomena and of the variations from these laws, cannot be accomplished by an Arctic expedition of the kind hitherto sent out. Such an expedition cannot remain for any length of time at a number of points, and can therefore furnish observations bearing only on time and place, which do not in the least enable us to conclude what would be the condition at another time.

It is otherwise with those scientific problems in which the establishment of facts is of importance, as in the majority of problems in natural history, and in many of the other regions of natural science and geography. For such problems an expedition of the ustal kind would accomplish very valuable results. For the solution of other problems the establishment of observing stations is desirable, from which, through as long a period as possible, observations of periodical phenomena should be undertaken. But in order to be able to generalise the results, corresponding observations should be made from time to time at intermediate stations and in regions lying in the neighbourhood. A German expedition would thus erect observing stations on particular points, and then would make such arrangements that, according to the special circumstances of the stations, or to accomplish special scientific objects, exploring journeys could be made from the stations as a basis, by land and water, in sledges, ships, or boats. This combined system of fixed stations and exploring journeys would give us at least the prospect, by the minute exploration of any particular region in which it might be employed, of enriching our knowledge with a plentiful supply of facts.

The problems indicated by the Commission for Arctic exploration can only be fully solved by means of a connected system of stations and exploring journeys in the Arctic region, and thus the way be opened up to the hitherto entirely unexplored portion. Explorations must thus, be carried on by the three great water approaches, 